Agr. Biol. Chem., 37 (5), $1057 \sim 1065,1973$

\title{
Utilization of Diammonium Citrate by Adult Rats
}

\author{
Mariko Yoshizawa, Teru Ishibashi, Masao Kametaka and Makoto Kandatsu* \\ Department of Agricultural Chemistry, Faculty of Agriculture, The University of Tokyo, Tokyo
}

Received October 5, 1972

In the 1st experiment, the utilization of diammonium citrate (DAC) as a non-essential nitrogen source was studied in comparison with glutamic acid. Adult rats fed the amino acid diet containing DAC in place of glutamic acid as a nonessential amino acid maintained their body weights and had nitrogen balances almost equal to those of rats on the glutamic acid containing diets.

In the 2 nd experiment, $\mathrm{DAC}-{ }^{-15} \mathrm{~N}$ was orally administered after the rats were fed the DAC diet for a month, and the distribution of ${ }^{15} \mathrm{~N}$ in the rats' bodies and excreta was examined at the 6th, 12th, 24th and 48th hr after administration.

At the $6 \mathrm{th} \mathrm{hr}, 85 \%$ of ${ }^{15} \mathrm{~N}$ intake was retained and $60 \%$ of ${ }^{15} \mathrm{~N}$ intake was found as protein $-{ }^{-15} \mathrm{~N}$. At the 48 th $\mathrm{hr}$, retained ${ }^{15} \mathrm{~N}$ was $83 \%$ and protein- ${ }^{-15} \mathrm{~N}$ increased $5 \%$ above that at the 6 th $\mathrm{hr}$. The ${ }^{15} \mathrm{~N}$ concentration of non-protein fractions was higher and changed more rapidly than that of protein fractions, especially in the blood, liver and small intestine.

These results seem to indicate that DAC was utilized by rats fed a diet, in which nonessential amino acids were completely replaced by DAC. Gastrointestinal microbes might hardly play any role in the utilization of dietary non-protein nitrogen under these experimental conditions.

Although the use of non-specific nitrogen by hens, ${ }^{1 \sim 51}$ pigs, ${ }^{6 \sim 8)}$ and rabbits ${ }^{9,10)}$ has been studied, there have been no reports on the practical use by monogastric animals.

In 1939, the possibility of utilization of ammonium nitrogen by monogastic animals was indicated by Foster et al., ${ }^{11}$ who observed the utilization of ammonia- $\mathrm{N}$ for amino acid synthesis in rats by feeding ammonium- ${ }^{15} \mathrm{~N}$ under the condition of low protein diets.

Earlier studies ${ }^{12 \sim 14)}$ concluded that the young rats fed diets containing only mixtures of non-specific nitrogen and essential amino acids as the nitrogen sources utilized the nonspecific nitrogen as nitrogen sources for nonessential amino acid synthesis. Ammonium butyrate and ammonium citrate were utilized when non-essential amino acids were replaced by ammonium salts, ${ }^{15 \sim 17}$ ) but the extent of utilization of non-specific nitrogen decreased when the diet contained the non-essential amino acid. This result indicated that the synthesis of carbon skeletons for amino group

* Azabu Veterinary College, Fuchinobe, Sagamihara-shi, Japan. acceptors was too slow to supply enough $a$-keto-glutaric acid $(a-\mathrm{KG})$ which was needed for the synthesis of amino acids. However, the utilization of ammonium salt was not improved even when ammonium salts and $a$-KG were supplied. ${ }^{18 ;}$

The purpose of this study was to know the direct evidence to change ammonia in the diet to body proteins and their distributions, and to study the possibility of utilization of nonspecific nitrogen. DAC was chosen as the typical non-specific nitrogens, because it permitted best growth in young rats on nonspecific nitrogens. ${ }^{13,15,16)}$ Firstly, changes of body weight and nitrogen balance of rats fed the diet which contained DAC as a nonessential nitrogen source were investigated. Secondly, distributions of DAC $-{ }^{15} \mathrm{~N}$ in organs and tissues were determined over the course of time to find out the extent of the contiribution of DAC- $\mathrm{N}$ in body protein synthesis.

\section{MATERIALS AND METHODS}

Expt. 1. To study the effect of DAC on nitrogen balance of rats, the rats were fed a diet containing 
Table I. Composition of Diets

\begin{tabular}{|c|c|c|c|c|}
\hline & \multicolumn{2}{|c|}{$4.5 \%$ diet } & \multicolumn{2}{|c|}{$6.5 \%$ diet } \\
\hline & A & B & $\mathrm{C}$ & D \\
\hline Soybean oil & $5.00 \%$ & $5.00 \%$ & $5.00 \%$ & $5.00 \%$ \\
\hline Cellulose powder & 5.00 & 5.00 & 5.00 & 5.00 \\
\hline Mineral mixture ${ }^{a}$ & 4.00 & 4.00 & 4.00 & 4.00 \\
\hline Vitamin mixture $^{b}$ & 0.28 & 0.28 & 0.28 & 0.28 \\
\hline Essential amino acid mixture ${ }^{c}$ & 2.09 & 2.09 & 3.02 & 3.02 \\
\hline Glutamic acid (Glu) & 2.41 & & 3.48 & \\
\hline Diammonium citrate (DAC) & & 1.85 & & 2.67 \\
\hline Corn starch adjusted to & 100 & 100 & 100 & 100 \\
\hline
\end{tabular}

a) Contains per $100 \mathrm{~g}$ of diet: $\mathrm{CaCO}_{3}, 1.20 \mathrm{~g} ; \mathrm{K}_{2} \mathrm{HPO}_{4}, 1.32 \mathrm{~g}$;

$\mathrm{CaHPO}_{4} \cdot 2 \mathrm{H}_{2} \mathrm{O}, 300 \mathrm{mg} ; \mathrm{MgSO}_{4} \cdot 7 \mathrm{H}_{2} \mathrm{O}, 20.1 \mathrm{mg} ; \mathrm{ZnCl}_{2}, 1.02 \mathrm{mg}$;

$\mathrm{CuSO}_{4} \cdot 5 \mathrm{H}_{2} \mathrm{O}, 1.20 \mathrm{mg} ; \mathrm{CoCl}_{2} \cdot 6 \mathrm{H}_{2} \mathrm{O}, 0.189 \mathrm{mg}$.

b), c) N.R.C. $(1962)^{25}$

DAC and an essential amino acid mixture. Male rats of the Donryu strain weighing $367 \mathrm{~g}$ to $490 \mathrm{~g}$ were pre-fed the stock diet, which contained $23.7 \%$ crude protein, and then 14 rats were divided into 4 groups.

The 1st group of 3 rats was fed diet A containing $4.5 \%$ amino acids, and the 2 nd group of 3 rats diet B, in which Glu-N was isonitrogenously replaced by DAC. The 3 rd group of rats was fed diet $\mathrm{C}$ containing $6.5 \%$ amino acids and the 4 th group of 4 rats diet $D$, isonitrogenously replaced by $\mathrm{DAC}$ in the same manner as in diet B. Table I shows the composition of the diets used. These four diets was calculated to have $4.04 \mathrm{Kcal} / \mathrm{g}$. Each rat was housed in an individual metabolism cage in a room in which the temperature $\left(22 \pm 3{ }^{\circ} \mathrm{C}\right)$ and humidity $(60 \pm 10 \%)$ were controlled, and was supplied diet at a daily rate of $18.2 \mathrm{~g}(16.0 \mathrm{~g}$ on a dry matter basis) at 5 p.m. and water ad libitum. Body weight was recorded every two days. Urine and feces were collected every day at $10 \mathrm{a} . \mathrm{m}$. and mixed every 2 days, and nitrogen of mixed samples was determined by the semimicro Kjeldahl method.

Expt. 2. To study the utilization of DAC by rats, DAC ${ }^{15} \mathrm{~N}$ was dosed and its distribution was determined in the course of time. Eight adult male rats were fed diet $\mathrm{D}$ for 30 days, and then they were fed the ${ }^{15} \mathrm{~N}$-labeled diet, the composition of which was the same as that of diet D but the DAC in which was labeled by ${ }^{15} \mathrm{~N}$ (DAC ${ }^{15} \mathrm{~N}$ of the diet, 30 atom \% excess). Every 2 animals were sacrificed by anesthesia with ether and bloodletting at 6,12,24 and $48 \mathrm{hr}$ after one dose. Two rats, which were killed at the 48 th $\mathrm{hr}$, were fed diet D (non-labeled) $24 \mathrm{hr}$ after feeding the labeled diet. The DAC- ${ }^{15} \mathrm{~N}$ diet contained 14.6 atom $\%$ excess ${ }^{15} \mathrm{~N}$, and therefore $14.6 \mathrm{mg}^{15} \mathrm{~N}$ per head was administered. $1 \%$ chromic oxide was added to the diet to study the passage of diet through the digestive tract.

Blood was collected by cutting the carotid. The stomach, small intestine, cecum, and rectum and colon were removed and their contents were washed out with $0.9 \% \mathrm{NaCl}$ solution. The liver, kidney, small intestine, cecum, rectum and colon, other viscera, skin and residuals (carcass) were separated and stored at $-27^{\circ} \mathrm{C}$. Trichloroacetic acid (TCA) solution was added to all samples so that the final concentration was $5 \%$. Samples were homogenized in a blender and centrifuged for $15 \mathrm{~min}$ at $10,000 \times g$. Precipitates were washed with $5 \%$ TCA solution 3 to 4 times in the same way. The precipitates obtained were called $\mathrm{PN}$ fractions and total supernatants, NPN fractions. Nitrogen content of both fractions was determined by the semi-micro Kjeldahl method. The amount of ${ }^{15} \mathrm{~N}$ was analysed by optical emission spectroscopy (No. $1 \sim 4^{15} \mathrm{~N}$ Analyzer Quisocomerz Statron) after converting nitrogen of the samples into $\left(\mathrm{NH}_{4}\right)_{2} \mathrm{SO}_{4}-\mathrm{N}$ and then into $\mathrm{N}_{2}$, according to the method of Kumazawa. ${ }^{19}$ ) To determine contents of $\mathrm{Or}_{2} \mathrm{O}_{3}, 5$ to $10 \mathrm{ml}$ of conc. $\mathrm{HNO}_{3}$ was added to each aliquot of samples in Kjeldahl flasks and dried. After cooling, $5 \mathrm{ml}$ of conc. $\mathrm{H}_{2} \mathrm{SO}_{4}, 1 \mathrm{ml}$ of $10 \% \mathrm{Na}_{2} \mathrm{MoO}_{4}$ and $5 \mathrm{ml}$ of $\mathrm{HClO}_{4}$ were added. Then the samples were decomposed until they become yellow or orange. Later, the samples were estimated spectrometrically at $430 \mathrm{~m} \mu^{201}$ using photospectrometer (Shimazu spectrometer 20).

\section{RESULTS}

Figure 1 shows the N-balance of rats fed the DAC and the Glu diets. At the level of $4.5 \%$ amino acids, average $\mathrm{N}$-balance (negative balance) on the Glu diet (A) was higher than that on the DAC diet (B). However, each value of the latter was within the maximum and minimum limits of the former. At the level of $6.5 \%$ amino acid, average $\mathrm{N}$-balance 


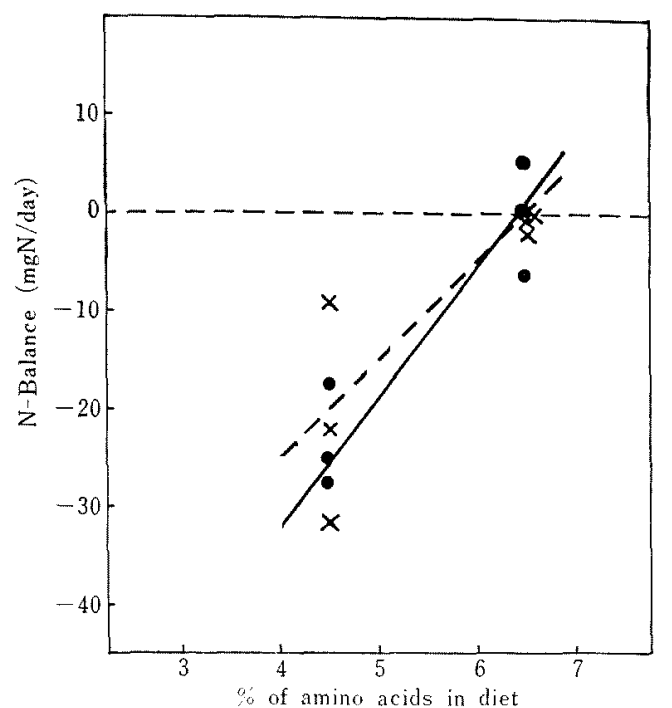

FIG. 1. Nitrogen Balance (N-Balance) on DAC Diets (-) and Glu Diets $(x--x)$.

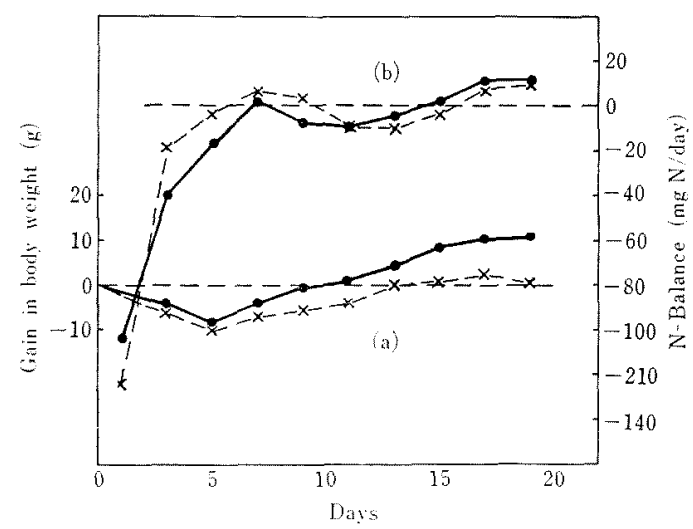

Frg. 2. Gain in Body Weight (a) and N-Balance (b) of the Rats fed 6.5\% Amino Acid Diets $(x--x)$ and Isonitrogenous DAC Diets

of both the DAC (D) and Glu (C) diet was maintained and values for individual rats showed almost no variation.

Figure 2 shows average gain in body weight (a) and the N-balance (b) of rats fed $6.5 \%$ amino diet (C) and DAC diet (D). Average gain in body weight of the rats fed both diets decreased during the first 5 days, then increased gradually. The N-balance of the two groups increased concomitantly with body weight gain and almost reached a plateau on the 5 th day for both diets. One rat on the DAC diet

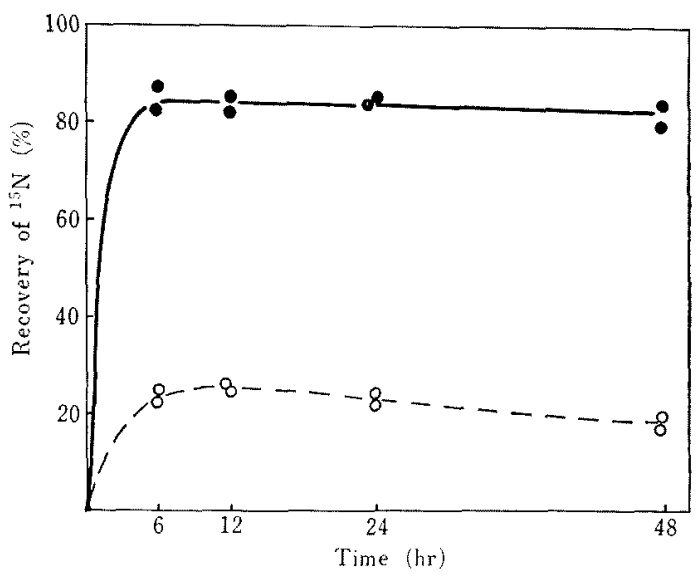

FIG. 3. Incorporation of ${ }^{15} \mathrm{~N}$ into Protein Nitrogen (PN) and Non-protein Nitrogen (NPN) of the Body. - ${ }^{15} \mathrm{~N}$ retained as $(\mathrm{PN}+\mathrm{NPN}) ; 100 \cdot\left({ }^{15} \mathrm{~N} \%\right.$ contents in gastrointestinal tract, feces and urine per ${ }^{15} \mathrm{~N}$ intake).

$0--{ }^{15} \mathrm{~N}$ recovered in non-protein fraction. Two rats were used each time.

(D) died 7 days after the start of the experiment. Its body weight and N-equilibrium were not maintained but no distinct lesion was found in the post-mortem examination.

The rats fed the DAC diet (D) gained a little more than those fed the Glu diet, but there was no difference in $\mathrm{N}$-balance between the two.

The present finding indicates that $\mathrm{DAC}-\mathrm{N}$ as well as Glu-N by adult rats was utilized when they were supplied non-specific nitrogen in diets at the maintenance level.

Results in Expt. 2 are summarized in Tables II to VI and Figs. 3 to 6 . Total ${ }^{15} \mathrm{~N}$ recovered was 96 to $109 \%$ of the intake in all cases. The amount of total $\mathrm{N}$ in the PN fractions of skin and carcass was rather large but ${ }^{15} \mathrm{~N}$ concentration in these fractions was so low that a major error in total calculated ${ }^{15} \mathrm{~N}$ contents was caused by these fractions.

Figure 3 shows the time course of ${ }^{15} \mathrm{~N}$ retained in the body. $85 \%$ of ${ }^{15} \mathrm{~N}$ intake had already been incorporated and $73 \%$ of this was found as protein- ${ }^{15} \mathrm{~N}$ at the 6 th hr. At the $48 \mathrm{th} \mathrm{hr}, 82 \%$ of ${ }^{15} \mathrm{~N}$ intake was retained and retained ${ }^{15} \mathrm{~N}$ showed hardly any decrease until this time. Therefore, it is concluded that DAC-N was highly retained and remained stable. In NPN fractions, ${ }^{15} \mathrm{~N}$ retained was 
TAble II. Distribution of ${ }^{15} \mathrm{~N} 6$ Hr after Dosing -

\begin{tabular}{|c|c|c|c|c|c|c|}
\hline & \multicolumn{3}{|c|}{ NPN fraction ${ }^{a}$} & \multicolumn{3}{|c|}{ PN fraction ${ }^{b}$ ) } \\
\hline & TNol & $\begin{array}{l}{ }^{16} \mathrm{~N} \\
\text { conc. }\end{array}$ & $\begin{array}{c}{ }^{15} \mathrm{~N} \\
\text { content }\end{array}$ & $\mathrm{TN}$ & $\begin{array}{l}{ }^{15} \mathrm{~N} \\
\text { conc. }\end{array}$ & $\begin{array}{l}{ }^{15} \mathrm{~N} \\
\text { content }\end{array}$ \\
\hline & \multicolumn{3}{|c|}{ atom $\%$} & \multicolumn{3}{|c|}{ atom $\%$} \\
\hline Liver & 46.2 & 0.825 & 407 & 274 & 0.195 & 572 \\
\hline Kidney & 13.9 & 1.18 & 176 & 57.1 & 0.30 & 183 \\
\hline Blood & 4.8 & 1.14 & 59 & 473 & 0.125 & 632 \\
\hline Small intestine & 32.3 & 0.31 & 107 & 125 & 0.12 & 161 \\
\hline Colon and rectum & 4.4 & 0.37 & 17 & 54.3 & 0.135 & 78 \\
\hline Other viscera & 90.8 & 0.195 & 189 & 307 & 0.035 & 116 \\
\hline Contents of stomach & 26.7 & 7.05 & 1540 & 10.4 & 0.685 & 76 \\
\hline Contents of small intestine & 0.1 & 0.225 & 0.3 & 2.8 & 0.28 & 8 \\
\hline Contents of colon and rectum & 0.6 & 0.23 & 0.2 & 2.5 & 0.255 & 7 \\
\hline Contents of cecum & 3.5 & 0.36 & 13 & 5.3 & 0.17 & 10 \\
\hline Skin & 168 & 0.22 & 395 & 3250 & 0.035 & 1220 \\
\hline Carcass $^{(1)}$ & 845 & 0.245 & 2220 & 6550 & 0.085 & 5960 \\
\hline Urine & 27.8 & 1.32 & 392 & & & \\
\hline Feces & 4.3 & 0.125 & 6 & 6.0 & 0.09 & 6 \\
\hline Total & 1270 & & 5520 & 11200 & & 9020 \\
\hline $\mathrm{N}$ intake & 90.0 & 14.6 & 14200 & & & \\
\hline $\begin{array}{l}\text { a) Supernatant by tre } \\
\text { b) Precipitate by treat } \\
\text { c) Total nitrogen } \\
\text { d) Carcass indicates a } \\
\text { This footnote is applic }\end{array}$ & $\begin{array}{l}\text { atment } w \\
\text { ment witl } \\
\text { rat's bo } \\
\text { able to } \mathrm{T}\end{array}$ & $\begin{array}{l}5 \% \text { TCA } \\
\% \text { TCA } \\
\text { without vi } \\
\text { TII IV }\end{array}$ & $\begin{array}{l}\mathrm{ra} \text {, conten } \\
\mathrm{V} .\end{array}$ & gastrointe & l tract a & skin. \\
\hline
\end{tabular}

TAble III. Distribution of ${ }^{15} \mathrm{~N} 12$ HR AFter Dosing

\begin{tabular}{|c|c|c|c|c|c|c|}
\hline & \multicolumn{3}{|c|}{ NPN fraction } & \multicolumn{3}{|c|}{ PN fraction } \\
\hline & TN & $\begin{array}{c}{ }^{15} \mathrm{~N} \\
\text { conc. }\end{array}$ & $\begin{array}{l}{ }^{15} \mathrm{~N} \\
\text { content }\end{array}$ & $\mathrm{TN}$ & $\begin{array}{l}{ }^{15} \mathrm{~N} \\
\text { conc. }\end{array}$ & $\begin{array}{l}{ }^{15} \mathrm{~N} \\
\text { content }\end{array}$ \\
\hline & $\mathrm{mg}$ & $\begin{array}{l}\text { atom } \% \\
\text { excess }\end{array}$ & $\mu \mathrm{g}$ & $\mathrm{mg}$ & $\begin{array}{l}\text { atom } \% \\
\text { excess }\end{array}$ & $\mu \mathrm{g}$ \\
\hline Liver & 49.0 & 0.745 & 391 & 242 & 0.27 & 700 \\
\hline Kidney & 14.3 & 0.66 & 101 & 63.4 & 0.185 & 125 \\
\hline Blood & 5.2 & 1.28 & 71 & 519 & 0.13 & 721 \\
\hline Small intestine & 28.7 & 0.465 & 142 & 88.3 & 0.25 & 236 \\
\hline Colon and rectum & 4.2 & 0.475 & 21 & 51.5 & 0.135 & 74 \\
\hline Other viscera & 94.8 & 0.265 & 268 & 299 & 0.135 & 432 \\
\hline Contents of stomach & 14.5 & 6.35 & 985 & 2.0 & 0.46 & 10 \\
\hline Contents of small intestine & 3.2 & 0.875 & 30 & 1.9 & 0.71 & 14 \\
\hline Contents of colon and rectum & 1.2 & 0.23 & 3 & 3.7 & 0.435 & 17 \\
\hline Contents of cecum & 3.8 & 0.71 & 29 & 5.5 & 0.46 & 27 \\
\hline Skin & 192 & 0.29 & 652 & 3740 & 0.065 & 2600 \\
\hline Carcass & 830 & 0.295 & 2620 & 7470 & 0.07 & 5590 \\
\hline Urine & 59.3 & 1.845 & 1170 & & & \\
\hline Feces & 11.1 & 0.335 & 40 & 13.8 & 0.16 & 23 \\
\hline Total & 1310 & & 6250 & 12500 & & 10600 \\
\hline $\mathrm{N}$ intake & 102.6 & 14.6 & 16020 & & & \\
\hline
\end{tabular}


Table IV. Distribution of ${ }^{15} \mathrm{~N} 24$ HR after Dosing

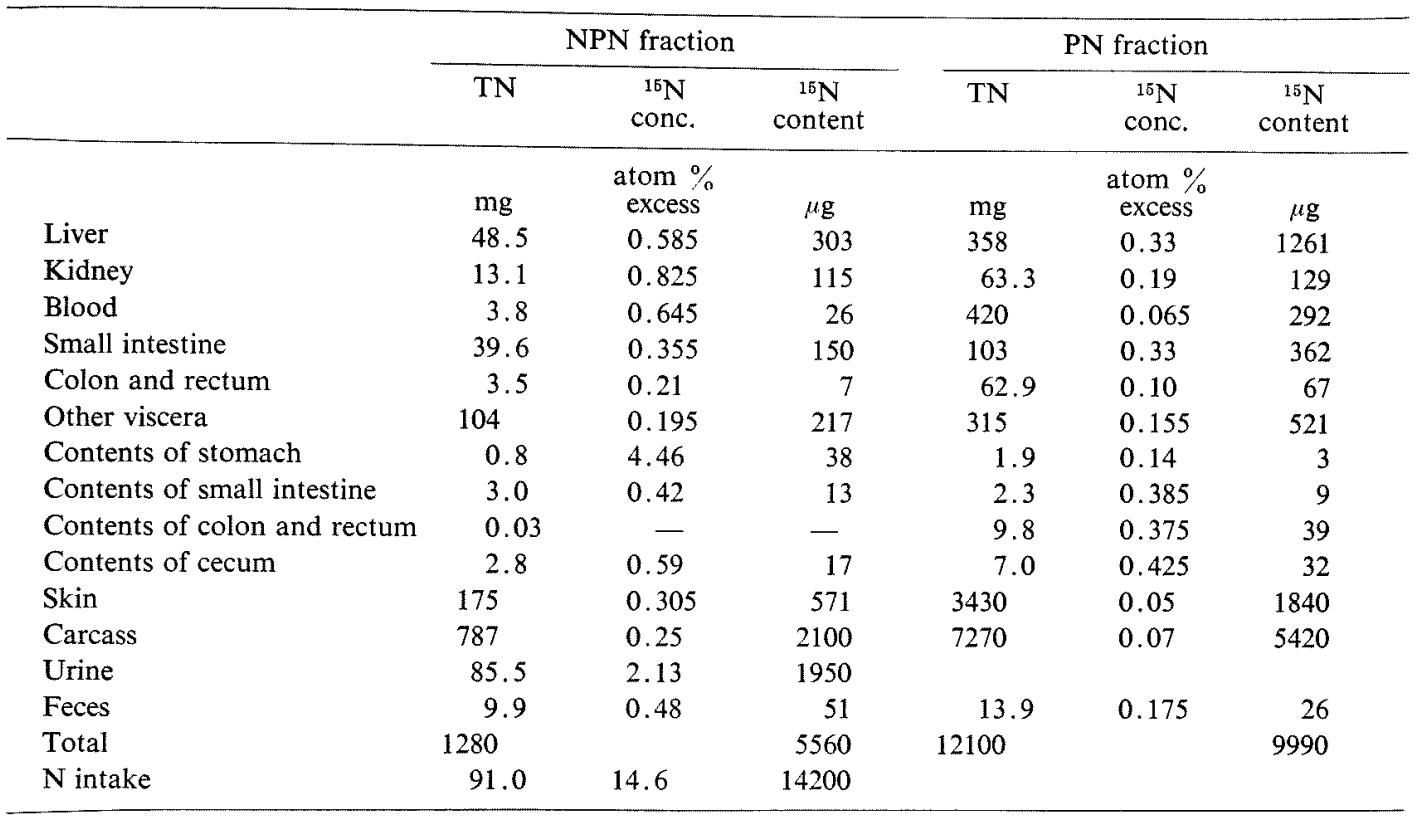

Table V. Distribution of ${ }^{15} \mathrm{~N} 48$ hr after Dosing

\begin{tabular}{|c|c|c|c|c|c|c|}
\hline & \multicolumn{3}{|c|}{ NPN fraction } & \multicolumn{3}{|c|}{ PN fraction } \\
\hline & $\mathrm{TN}$ & $\begin{array}{l}{ }^{15} \mathrm{~N} \\
\text { conc. }\end{array}$ & $\begin{array}{c}{ }^{15} \mathrm{~N} \\
\text { content }\end{array}$ & $\mathrm{TN}$ & $\begin{array}{l}1.5 \mathrm{~N} \\
\text { conc. }\end{array}$ & $\begin{array}{c}{ }^{15} \mathrm{~N} \\
\text { content }\end{array}$ \\
\hline & $\mathrm{mg}$ & $\begin{array}{c}\text { atom } \% \\
\text { excess }\end{array}$ & $\mu \mathrm{g}$ & $\mathrm{mg}$ & $\begin{array}{l}\text { atom } \% \\
\text { excess }\end{array}$ & $\mu \mathrm{g}$ \\
\hline Liver & 42.3 & 0.485 & 219 & 350 & 0.15 & 567 \\
\hline Kidney & 16.6 & 0.145 & 26 & 58.9 & 0.045 & 28 \\
\hline Blood & 3.7 & 0.25 & 10 & 456 & 0.09 & 439 \\
\hline Small intestine & 34.5 & 0.25 & 92 & 99.9 & 0.055 & 59 \\
\hline Colon and rectum & 4.5 & 0.305 & 15 & 59.5 & 0.11 & 79 \\
\hline Other viscera & 97.6 & 0.195 & 203 & 253 & 0.175 & 475 \\
\hline Contents of stomach & 0.2 & 0.53 & 1 & 0.05 & - & - \\
\hline Contents of small intestine & 3.0 & 0.385 & 12 & 1.5 & 0.27 & 4 \\
\hline Contents of colon and rectum & 1.1 & 0.42 & 5 & 6.1 & 0.335 & 22 \\
\hline Contents of cecum & 4.1 & 0.52 & 23 & 11.8 & 0.385 & 49 \\
\hline Skin & 192 & 0.205 & 420 & 3340 & 0.065 & 2320 \\
\hline Carcass & 875 & 0.18 & 1690 & 6500 & 0.08 & 5570 \\
\hline Urine & 143 & 1.54 & 2350 & & & \\
\hline Feces & 25.4 & 0.385 & 105 & 30.8 & 0.38 & 126 \\
\hline Total & 144 & & 5160 & 11200 & & 9740 \\
\hline $\mathrm{N}$ intake & 100.2 & 14.6 & 15650 & & & \\
\hline
\end{tabular}

almost constant from the 6 th to 24 th $\mathrm{hr}$, then decreased slightly until the $48 \mathrm{th} \mathrm{hr}$. The percentage of non-protein- $\mathrm{N}$ in respect to protein- $\mathrm{N}$ in the whole animal was about $11 \%$ and that of $\mathrm{NPN}_{-}{ }^{15} \mathrm{~N}$ to $\mathrm{PN}-{ }^{15} \mathrm{~N}$ was 29 to $21 \%$ during the experimental period. These result indicated that $\mathrm{DAC} \cdot{ }^{15} \mathrm{~N}$ incorporated into the NPN fraction was twice in concentrations as much as that into the PN fraction, but the amount of ${ }^{15} \mathrm{~N}$ incorporated into protein- $\mathrm{N}$ was twice as much as that incorporated into the NPN fraction and the incorpo- 


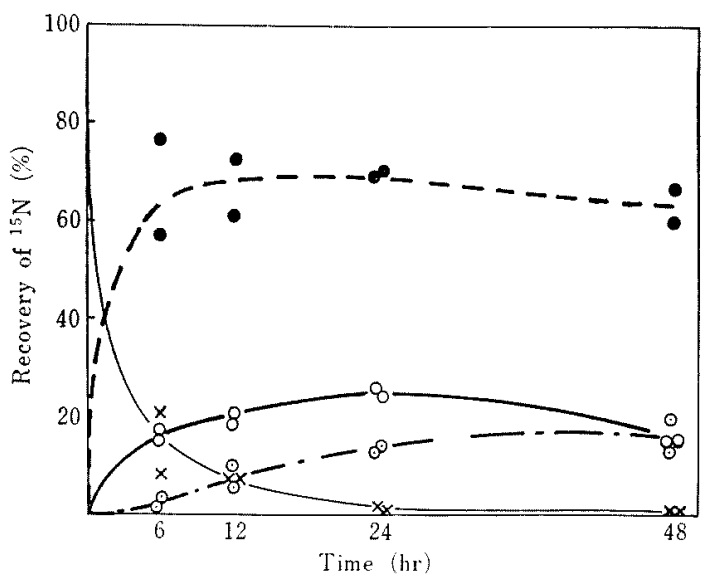

Frg. 4. Distribution of ${ }^{15} \mathrm{~N}$ after Diammonium Citrate- ${ }^{15} \mathrm{~N}$ was Orally Administrered to Rats.

$\times-\times{ }^{15} \mathrm{~N}$ in gastrointestinal tract.

-.- - - ${ }^{15} \mathrm{~N}$ excreted in urine and feces.

$O-O^{15} \mathrm{~N}$ in viscera.

${ }^{15} \mathrm{~N}$ in carcass.

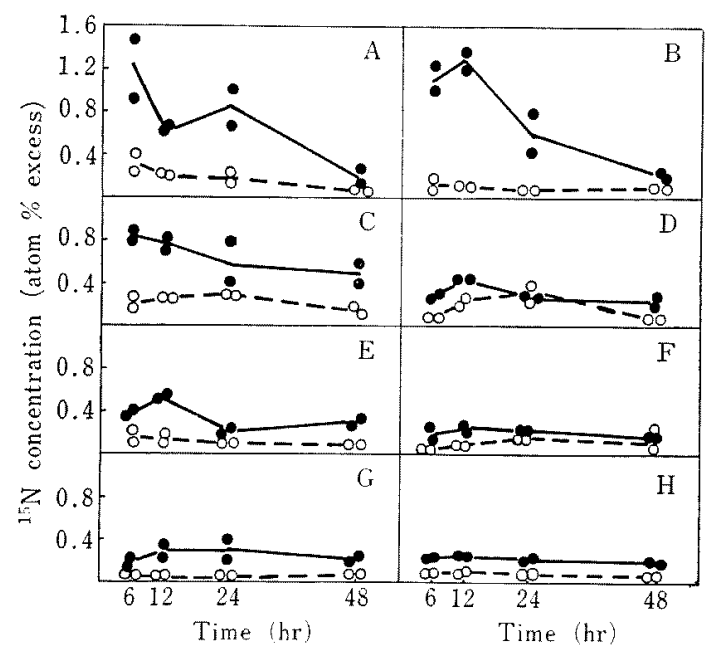

FrG. 5. Changes of ${ }^{15} \mathrm{~N}$ Concentration in Several Parts of the Body.

- - - NPN fraction; $0--0, P N$ fraction; A, kidney; B, blood; C, liver; D, small intestine; $E$, rectum and colon; $\mathrm{F}$, other viscera; $\mathrm{G}$, skin; $\mathrm{H}$, carcass.

rated ${ }^{15} \mathrm{~N}$ was retained almost unchanged during $48 \mathrm{hr}$ (Tables II to $\mathrm{V}$ ).

Figure 4 shows the distribution of ${ }^{15} \mathrm{~N}$ in each part of body and excreta. The percentage of ${ }^{15} \mathrm{~N}$ in the viscera in respect to ${ }^{15} \mathrm{~N}$ in skin and carcass was 23 to $33 \%$ and that of viscera- $\mathrm{N}$ in respect to skin and carcass- $\mathrm{N}$ was about $12 \%$. Therefore, the rate of ${ }^{15} \mathrm{~N}$ incorporation into the viscera was about twice as high as that into the carcass at least until the 48th hr. The peak of ${ }^{15} \mathrm{~N}$ incorporation in the viscera appeared at the 24th hr and at that time, the ratio of ${ }^{15} \mathrm{~N}$ into the $\mathrm{PN}$ fraction to ${ }^{15} \mathrm{~N}$ into the NPN fraction was larger than that at the 6 th $\mathrm{hr}$ (Tables II and IV)

Figure 5 shows the time course of ${ }^{15} \mathrm{~N}$ concentration in the viscera, skin and carcass. High ${ }^{15} \mathrm{~N}$ concentration was found in the kidneys, blood, liver and small intestine, but ${ }^{15} \mathrm{~N}$ concentration in skin, carcass and other viscera was relatively low. The peaks of ${ }^{15} \mathrm{~N}$ concentration in NPN fractions of liver and kidney were assumed to be found before the 6th hr and those of blood, small intestine and rectum and colon appeared at about the 12th hr. Maxmal ${ }^{15} \mathrm{~N}$ concentration in $\mathrm{PN}$ fractions of liver and small intestine $(0.33$ atom \% excess) appeared at the $24 \mathrm{th} \mathrm{hr}$, and this value was the highest for ${ }^{15} \mathrm{~N}$ concentration in other PN fractions. The ${ }^{15} \mathrm{~N}$ concentration in $\mathrm{PN}$ fraction of liver was 0.15 atom $\%$ excess and that of small intestine was 0.045 atom $\%$ excess, so the half life of liver protein ${ }^{15} \mathrm{~N}$ was estimated to be about $24 \mathrm{hr}$ and that of small intestine ${ }^{15} \mathrm{~N}$ was shorter than that of liver protein. NPN $-{ }^{15} \mathrm{~N}$ concentration in blood varied widely and rapidly and its half life was estimated to be $11.5 \mathrm{hr}$, but the amount of NPN in the blood was very slight. ${ }^{15} \mathrm{~N}$ concentration in the PN fraction of the blood was as low as in skin and carcass, in which ${ }^{15} \mathrm{~N}$ concentration was low in both NPN and PN fractions. ${ }^{15} \mathrm{~N}$ was incorporated into both NPN and PN

Table VI. Distribution of $\mathrm{Cr}_{2} \mathrm{O}_{3}$ in GastroINTESTINAL TRACT AND FECES (\% of intake)

\begin{tabular}{lrrrr}
\hline & \multicolumn{4}{c}{ Time after dosing (hr) } \\
\cline { 2 - 5 } & 6 & 12 & 24 & 48 \\
\hline Stomach & 59 & 21 & 2 & 0 \\
Small intestine & 9 & 13 & 5 & 1 \\
Cecum & 14 & 21 & 24 & 1 \\
Rectum and colon & 13 & 13 & 26 & 1 \\
Feces & 3 & 29 & 38 & 90 \\
Total & 97 & 95 & 95 & 93 \\
\hline
\end{tabular}


fractions of skin faster than in the carcass, which was mainly occupied by muscle.

Table VI shows the percentage of $\mathrm{Cr}_{2} \mathrm{O}_{3}$ in the digestive tract and feces in respect to $\mathrm{Cr}_{2} \mathrm{O}_{3}$ intake. $38 \%$ of intake was excreted during $24 \mathrm{hr}$, and $90 \%$ was excreted by the $48 \mathrm{th} \mathrm{hr}$. Only $7 \%$ of $\mathrm{Cr}_{2} \mathrm{O}_{2}$ intake was found in the stomach and small intestine at the 24th hr, therefore most of the ingesta might have passed through the intestine or been absorbed until the 24th hr.

Figure 6 shows the time course of ${ }^{15} \mathrm{~N}$ concentration and contents of $\mathrm{Cr}_{2} \mathrm{O}_{3}$ in the gastrointestinal tract, feces and urine. Although the ${ }^{15} \mathrm{~N}$ concentration of the contents of the digestive tract was high, ${ }^{15} \mathrm{~N}$ content was slight except in the stomach at the 6th

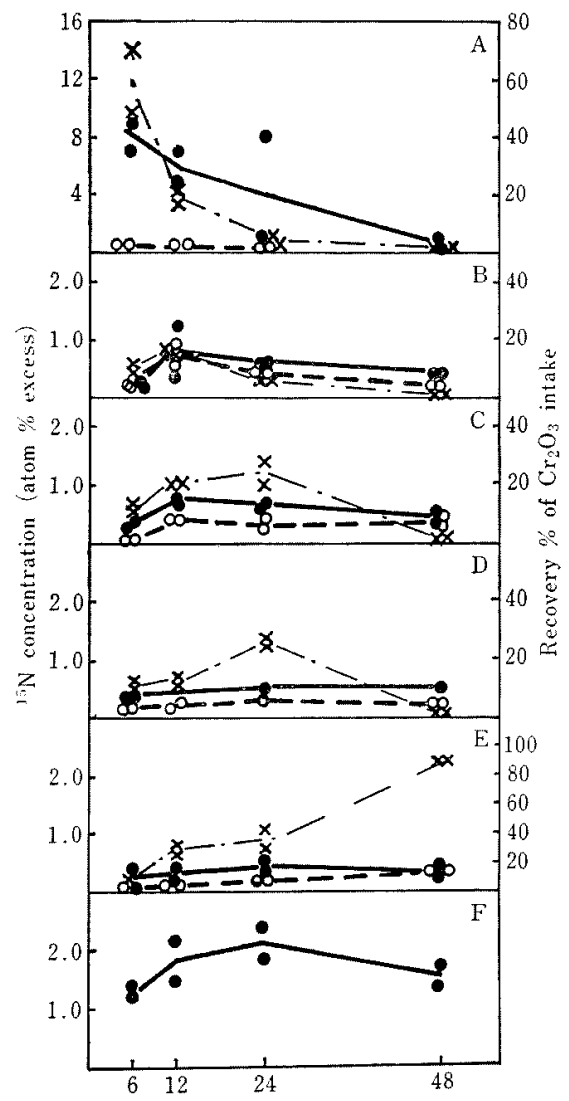

FIG. 6. Distribution of $\mathrm{N}^{15}$ and $\mathrm{Cr}_{2} \mathrm{O}_{3}$ in Gastrointestinal Tract, Feces and Urine.

$O-\mathrm{O}, \mathrm{PN} ;-\longrightarrow, \mathrm{NPN} ; \times-\cdot-x, \mathrm{Cr}_{2} \mathrm{O}_{3} ; \mathrm{A}$, stomach; $B$ intestine; $C$ cecum; $D$, rectum and colon; $E$, feces; $F$, urine. and 12th hr (Table II to V). Since $59 \%$ of $\mathrm{Cr}_{2} \mathrm{O}_{3}$ intake was found in the stomach at the 6th $\mathrm{hr}$, about half of the intake was thought to remain in the stomach, whereas the amount of $\mathrm{N}$ decreased to $29 \%$ of $\mathrm{N}$ intake and that of ${ }^{15} \mathrm{~N}$ to $11 \%$ of ${ }^{15} \mathrm{~N}$ intake. From these results it can be pointed out that DAC-N was either removed or absorbed from the stomach more rapidly than the other components of the diet. At the 6th $\mathrm{hr}, \mathrm{PN}$ and $\mathrm{PN}-{ }^{15} \mathrm{~N}$ were detected in the stomach. They could be derived from any digestive fluid and ${ }^{15} \mathrm{~N}$ containing feces of rats coprophaged, because the diet contained no proteins. In the small intestine and cecum, the peaks of ${ }^{15} \mathrm{~N}$ concentration were found at the 12 th hr. From the fact that 2 to $3 \%$ of $\mathrm{Cr}_{2} \mathrm{O}_{3}$ intake remained throughout the digestive tract at the $48 \mathrm{th} \mathrm{hr}$ coprophaged feces were prosumed, if any, to be less than 2 to $3 \%$ of total $\mathrm{N}$ intake. Therefore, it is unlikely that microbial activities in the digestive tract would contribute to NPN utilization.

The apparent digestibilities of ${ }^{15} \mathrm{~N}$, NPN and $\mathrm{N}$ calculated from Table IV were 99, 89 and $74 \%$, respectively.

\section{DISCUSSION}

From the data in Expt. 1, it is obvious that DAC orally administered to adult rats was utilized as effectively as a non-essential amino acid (Glu) when rats were supplied dietary nitrogen at the maintenance level. This result support the previous reports that amino acid diets containing ammonium salt in place of a non-essential amino acid showed the same effect on growth of growing rats $^{13,15}$ and on young adult rats. ${ }^{16)}$

These results indicate a possibility that ammonium salt- $\mathrm{N}$ supplied to monogastric animals could be incorporated into $a$-amino- $\mathrm{N}$ and then used for the synthesis of protein- $\mathrm{N}$ by the same pathway as non-essential amino acids. There is another possibility that ammonium salt- $\mathrm{N}$ might be excreted rapidly and selectively, but apparently utilized because of decrement of the body protein turnover and/or 
increment of reutilization of the body protein. The latter possibility, if any, might be minor because growing rats were used in these experiments, but this possibility can not be ruled out.

In Expt. 2, DAC $-{ }^{15} \mathrm{~N}$ was hardly excreted in feces and $15 \%$ of ${ }^{15} \mathrm{~N}$ intake was found in urine for 2 days. During the same period, $83 \%$ of DAC- ${ }^{15} \mathrm{~N}$ intake was retained, most of it existing as protein-N. Thus, it is concluded that DAC was not merely transported through the intestinal wall but also utilized as a nitrogen source for body protein synthesis.

The incorporation of $\mathrm{DAC}-{ }^{16} \mathrm{~N}$ into the viscera skin and carcass when feeding DAC is thought to be similar to that when feeding protein. ${ }^{22)}$ Sprinson et al. ${ }^{23)}$ reported that ammonium salt- ${ }^{15} \mathrm{~N}$ injected subcutaneously changes to $a$-amino- $\mathrm{N}$ and its ${ }^{15} \mathrm{~N}$ pattern of amino acids is similar to that when Glu- ${ }^{15} \mathrm{~N}$ is injected subcutaneously. These facts support the conclusion that the DAC diet was utilized at almost the same efficiency as the normal diet without ammonium salts. However, in our experiment half life in some parts of rats' bodies was shorter than that reported by Tompson et al. ${ }^{24)}$ and Buchanan. ${ }^{26)}$ This difference might be due to the use of a different isotope, and partly to a different administration period of the isotope, but on the other hand, the presence of proteins with more rapid turnover may also be assumed.

The role of microorganisms in the cecum through which non-specific nitrogen was thought to be incorporated into protein, especially in the case of urea, ${ }^{21}$ is not important for the utilization of DAC-N by the rat.

One of the problems in the future is to know when and where ammonium salt- $\mathrm{N}$ is changed to amino acid- $\mathrm{N}$ in monogastric animals and whether ammonium salt can be utilized practically.

One of rats fed the DAC diet in our experiment died, and the same observation has been reported by Ichihara et al. ${ }^{17)}$ The reason for this is not obvious yet, but these rats might not be able to adapt to a diet with such a high level of ammonium.

Acknowledgement. The authors wish to thank Professor K. Kumazawa, Mr. Y. Arima and Miss Y. Akiyama for their technical assistance and measurements of ${ }^{15} \mathrm{~N}$.

\section{REFERENCES}

1) D. W. F. Shannon, R. Blair and J. P. F. D'Mello, Brit. Poult. Sci., 10, 381 (1969).

2) R. J. Young, M. Griffith, I. D. Desai and M. L. Scott, Poult. Sci., 44, 1428 (1965).

3) S. D. Farlin, V. S. Garrigus, E. E. Hatfield and R. J. Conbon, J. Nutr., 94, 32 (1968).

4) R. A. Bloomfield, A. A. Leiter and R. P. Willson, Arch. Biochem. Biophs., 129, 196 (1969).

5) D. W. F. Shannon, R. Blair, J. M. McNab and D. J. W. Lee, Proc. Nutr. Soc., 29, 23A (1970).

6) C. H. Liu, V. W. Hays, H. J. Svec, D. V. Catron, G. C. Ashton and V. C. Speer, J. Nutr., 57, 241 (1955).

7) L. E. Hanson and E. F. Ferrin, J. Animal Sci, 14, 43 (1955).

8) E. T. Kornegay, V. Mosanghini and R. D. Snee, J. Nutr., 100, 330 (1970).

9) Y. Nakazima and M. Kandatsu, Nippon Nogeikagaku Kaishi, 38, 423 (1964).

10) J. O. L. King, Brit. Vet. J., 127,523 (1971).

11) G. L. Foster, R. Schoenheimer and D. Rittenberg, J. Biol. Chem., 127, 319 (1939).

12) H. A. Lardy and G. Feldott, ibid., 186, 85 (1950).

13) M. Recheigl Jr, J. K. Loosli and H. H. Williams, J. Nutr., 63, 177 (1957).

14) W. C. Rose and E. E. Dekker, J. Biol Chem., 203, 107 (1956).

15) W. C. Rose, L. C. Smith, M. Womack and M. Shane, ibid., 181, 307 (1949).

16) D. V. Frost and H. R. Sandy, ibid., 189, 249 (1951).

17) Y. Ichihara, S. Kiriyama and A. Yoshida, Eiyo To Shokuryo, 23, 14 (1970).

18) O. H. Gaebler and H. C. Choitz, Metabolism, 14, 819 (1965).

19) K. Kumazawa, Kagaku To Seibutsu, 8, 246 (1970).

20) F. W. Hill and D. L. Anderson, J. Nutr., 64, 587 (1958).

21) H. L. Kornberg, R. E. Davis and D. R. Wood, Biochem. J., 56, 355 (1964).

22) J. Twonbley, and J. H. Meyer, J. Nutr., 74, 453 (1961).

23) D. B. Sprinson and D. Rittenberg, J. Biol. Chem., 180, 707 (1949).

24) R. C. Tompson and J. E. Ballon, ibid, 233, 795 (1956). 
25) "Nutrient Requirements of Laboratory Animals" ed. by the Committee on Animal Nutrition, National Academy of Science National Research
Council Pub. 990 1962, p. 54 and 68.

26) D. L. Buchanan, Arch. Biochem. Biophys., 94, 500 (1961). 